\title{
THE FLORISTIC DIFFERENTIATION OF MICROHABITATS WITHIN KURGANS IN THE DESERT STEPPE ZONE OF SOUTHERN UKRAINE
}

\author{
BARBARA SUDNIK-WÓJCIKOWSKA ${ }^{1}$, IVAN I. MOYSIYENKO² \\ ${ }^{1}$ Department of Plant Ecology and Environmental Conservation, Warsaw University \\ Al. Ujazdowskie 4, 00-478 Warsaw, Poland \\ e-mail: barbara.sudnik@uw.edu.pl \\ 2 Department of Botany, Kherson State University \\ Str. 40 let Oktriabrya 27, 73000 Kherson, Ukraine \\ e-mail:Vanvan@ksu.ks.ua
}

(Received: January 30, 2007. Accepted: June 25, 2007)

\begin{abstract}
Results of the studies on the floristic biodiversity of the kurgans in the Pontic desert steppe of the Black Sea Lowland (Kherson Region) are presented. Twenty-six of about 130 kurgans higher than $3 \mathrm{~m}$, distributed over an area of approx. $1500 \mathrm{~km}^{2}$, were surveyed and the flora of 5 microhabitats within every kurgan (top, southern and northern slope, southern and northern foot) was examined. The richness of the kurgan flora is estimated at 305 species. Species of alien origin constituted $23 \%$ of the total flora, which indicates limited anthropogenic influence. Species of two classes, Festuco-Brometea and Stellarietea mediae were predominant, which also confirmed the semi-natural character of the kurgan flora. The lowest number of species was recorded on top, which was relatively rich in synanthropes, particularly therophytes (Stellarietea mediae). The north side was richer in species than the south side of the kurgans. Steppe species were the most stable and important component of the flora of the slopes $(45-47 \%$ of the species represented the class Festuco-Brometea). The total flora of the foot contained more species and was more diversified than the flora of the slopes (although the mean number of species was similar in both habitats), but each species occurred at low frequency. There was a higher proportion of species which were introduced from the area surrounding the kurgans, e.g. weeds, halophytes, meadow species, as well as trees which are rarely found in the desert steppe zone. In spite of the small size of the kurgans, significant differences between the floristic composition of the various microhabitats were detected.
\end{abstract}

KEY WORDS: flora of kurgans, barrow flora, microhabitats within a kurgan, floristic diversity, Pontic desert steppe zone, Kherson Region.

\section{INTRODUCTION}

It is striking that, so far, relatively few botanical studies have focused on kurgans in Ukraine, whose number is estimated at over 50,000 (e.g.: Paczoski 1917; Kondratyuk and Chuprina 1992). This may be due to cultural reasons, such as respect for burial grounds with human remains, traditions dating back to Scythian times (for the symbolism of the ring and dome, see e.g. Smirnov 1974; Kubczak 1978). Another problem faced by researchers dealing with barrows is the difficulty in reaching the study sites: they are usually a considerable distance from any settlements, or situated among vast cultivated fields, etc. However detailed archaeological studies of kurgans have been carried out for more than 100 years (Artemenko et al. 1975-1985; Shilov 1991; Olenkovsky 1997). In addition, the illegal activities of archaeological looters within the barrows have occurred for thousands of years.
Barrows, or burial mounds, are found throughout the temperate zone in Eurasia, particularly in Great Britain, the Netherlands, France, Germany, Poland, Hungary, Ukraine, Russia, Kazakhstan, and Mongolia. The flora of kurgans has been investigated in many countries, e.g. in Hungary (Barczi and Joó 2000, 2002; Barczi 2003), Bulgaria (Paczoski 1933), Poland (e.g.: Cwener and Towpasz 2003; Cwener 2004, 2005). Undoubtedly, Paczoski's publication was among the first of the pioneering floristic works. The above author, who did his research in the steppe zone of the Black Sea Region for over 20 years, did not conduct separate studies of the kurgan flora in Ukraine. After leaving Russia (1923) and on the expedition to Bulgaria (the kurgan of King Władysław Warneńczyk) he wrote: "...I have an idea to describe the plant cover of this kurgan, because this type of vegetation, as well as the vegetation of Ukrainian kurgans, can play an important role in the restitution of the steppe, which on the plains was sub- 
ject to the strongest anthropogenic transformation." (Paczoski 1933). These words became the motto of our research.

Studies on the flora of kurgans are just one of the many wide-scale investigations carried out on kurgans within the steppe and forest-steppe zones, which were initiated through collaboration between Polish and Ukrainian research workers in 2004. The first stage of the study involved the desert steppe zone. A full list of species and a general description of the kurgan flora from the above climate-vegetation zone have already been published in the work of Moysiyenko and Sudnik-Wójcikowska (2006).

Although the barrows are small, the habitat conditions vary within them. The particular microhabitats, i.e. the top, slopes and foot, as well as the north and south facing sides of the kurgan differ from each other. Therefore, the following question needs to be answered: to what degree do the microhabitats differ from each other, i.e. how does the combination of abiotic factors (moisture, insolation, slope exposure, soil salinity) determine the species composition within the particular microhabitats.
Hypothesis: In spite of the relatively small size of the kurgans, significant differences in species composition are found between microhabitats distinguished within kurgans in the desert steppe zone.

\section{THE INVESTIGATED AREA}

The studied area (Fig. 1A, B) is situated within the west and central Pontic desert steppe zone, which stretches as a thin strip in the south of Ukraine, along the coast of the Black Sea, (from the mouth of the Dnieper River to the western part of the Azovian Sea coast) and in the north part of the Crimea (Bilyk et al. 1973; Lavrenko et al. 1991; Bohn et al. 2000).

The survey was carried out in the southern part of the Black Sea Lowland and the south-western part of the Kherson Region (Gola Prystan district and the western part of Skadovsk district), in the weakly structured plains along the northern coast of the Black Sea (Fig. 1B). The study area was limited on the north by Dniprovski Liman, on the

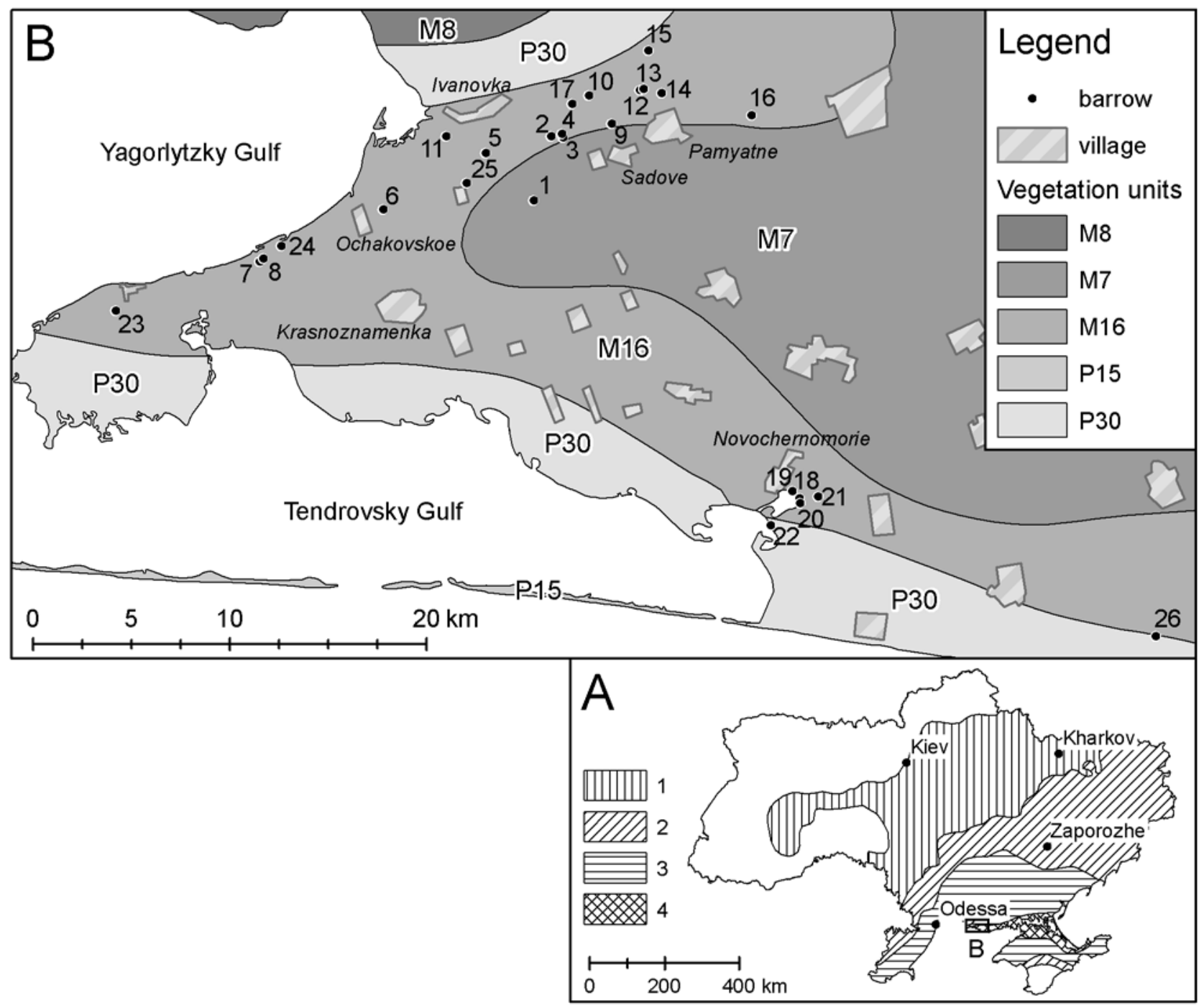

Fig. 1. A) the location of the investigated area and the various types of steppes in Ukraine: 1 - forest-steppe; 2 - fescue/feather-grass, rich forbs steppe; 3 fescue/feather-grass, poor forbs steppe; 4 - wormwood/sod-grass steppe; B) the investigated area and location of the 26 selected kurgans against a background of the vegetation units based on the Map of the Natural Vegetation of Europe [Bohn et al. 2000]. Abbreviations: M7 - Pontic hemi-psammophytic herb-grass steppes; M8 - Pontic psammophytic herb-grass steppes; M16 - west and central Pontic desert steppes; P15 - west and central Pontic sand dune vegetation; P30 - west Pontic halophytic vegetation. 
west by Yagorlytzki Gulf, on the south by Tendrovsky Gulf and on the east by the road from Gola Prystan to Lazurne. The investigated kurgans were located over an area estimated at around $1500 \mathrm{~km}^{2}$.

The area lies within the southern part of the temperate continental climate zone with hot summers and short, mild, snow-poor winters and with prolonged precipitation-free periods. The total annual precipitation is below $350 \mathrm{~mm}$; total summer rainfall is greater than total winter rainfall; maximum rainfall occurs in June and July. Mean July temperature is $+23^{\circ} \mathrm{C}$, mean temperature for January - not greater than $-3^{\circ} \mathrm{C}$; extreme temperatures: $+39^{\circ} \mathrm{C}$ in summer, $-31^{\circ} \mathrm{C}$ in winter (Boiko et al. 1998).

The surface of the territory is almost flat. There are no rivers. The waters of saline or brackish lakes evaporate completely in the summer, and the dry bottoms of the lakes are covered with crust salt in the central part and with obligatory halophytes in the peripheral part.

The soils vary within the area investigated but they are dominated by solonetz-like dark chestnut soils and by a combination of chestnut soils with solonetz-solonchak soils (Boiko et al. 1998; Sklyar and Khilchenko 1969).

The plant cover also varies due to the diversity of substrata (Boiko et al. 1998; Lavrenko et al. 1991). In accordance with the classification scheme adopted in the Map of the Natural Vegetation of Europe (Bohn et al. 2000) some units of steppe vegetation can be distinguished in this area: west and central Pontic desert steppe (M16) is the dominant part of the desert steppe, in the eastern part Pontic hemi-psammophytic herb-grass steppe (M7) is recorded. West Pontic halophytic vegetation (P30) dominates on the coast.

In the investigated area Pontic steppe vegetation occurs in combination with halophyte and subhalophyte communities of solonetz, solonchak, and halophyte meadows in the lower situated places. The desert steppe is mainly used for extensive pasturage (herds of sheep have been replaced by a much smaller number of cows) and only in some parts as arable fields, some of which have been gradually abandoned since the 1960s-1970s. The increase of salt in the soil seems to be a result of the contemporary transgression of the Black Sea, as well as the consequence of the previous artificial watering of the fields.

Most of the kurgans located in the desert steppe are of Scythian origin and their age is estimated at 2500 years. In the study area there are ca. 130 kurgans higher than $3 \mathrm{~m}$. Some of the low kurgans which were found within the cultivated fields had been ploughed up or completely destroyed. A total of 26 kurgans were investigated (D1-26 - Fig. 1B). The criteria used for selecting the barrows are introduced in the Material and methods section. Due to problems in establishing the location of the kurgans on archaeological and geo-physical maps, GPS was used to locate the barrows (for data - see Moysiyenko and Sudnik-Wójcikowska 2006).

The abiotic conditions in various parts of the kurgans were not investigated in detail. The important role of slope exposure (north and south), which in turn may result in differences in insolation and temperature within the barrow seems to be self-evident. Differences in moisture levels between the various parts of the kurgans are also observed. At the foot of a barrow where the ground slopes downward more gently, the moisture conditions are more favourable
TABLE 1. The $\mathrm{pH}$, salt and anion content in the particular microhabitats within kurgan D2 and in its immediate vicinity.

\begin{tabular}{lccc}
\hline Microhabitat & $\mathrm{pH}$ & $\begin{array}{c}\text { Total amount } \\
\text { of anions } \\
(\mathrm{cmol} / 100 \mathrm{~g})\end{array}$ & $\begin{array}{c}\text { Total amount } \\
\text { of salt } \\
(\%)\end{array}$ \\
\hline Top (T) & 5.8 & 1.08 & 0.072 \\
South slope (Ss) & 5.3 & 1.34 & 0.089 \\
North slope (Sn) & 5.2 & 1.06 & 0.069 \\
South foot (Bs) & 5.6 & $\left.7.92^{*}\right)$ & 0.477 \\
North foot (Bn) & 5.7 & 2.18 & 0.137 \\
Surroundings (south part) & 7.8 & 25.80 & 1.538 \\
Surroundings (north part) & 6.7 & 24.70 & 1.492 \\
\hline
\end{tabular}

$\left.{ }^{*}\right)$ the higher content of salt at the south foot $(\mathrm{Bs})$ of a kurgan is associated with the close vicinity of a saline lake

for the growth of plants than on the dried up top or slopes. The contact zone between the kurgans and the surrounding pastures is barely visible. Sometimes small depressions develop at the edge of the kurgans as a result of the piling up of earth used to make the barrows.

Considerable differences in the levels of soil salinity between the various parts of a kurgan were also found (the preliminary data collected by the authors in 2005 confirmed these observations - Table 1). Salinity levels tend to be lower in the upper part of a kurgan due to limited infiltration and salt runoff (the washing out of salt from the soil during short periods of intensive rainfall). The foot of a barrow represents the seriously salt-affected area due to its close vicinity to marine water as well as saline and brackish lakes. The depression which developed at the edge of the kurgans as well as land use within their immediate surroundings also play an important role.

Anthropogenic influences are sometimes detected on top of the barrows, although triangulation towers are rarely built in these plain territories. Signs of archaeological activity are infrequently seen. Some of the kurgans are still used as cemeteries.

\section{MATERIAL AND METHODS}

Floristic studies were carried out during the growing seasons of 2004 and 2005. Every kurgan was visited 3 times (in spring, summer and autumn). The following criteria were used to select the 26 kurgans:

- the height of the kurgans; those less than $3 \mathrm{~m}$ in height were not considered; the height ranged from 3 to $10 \mathrm{~m}$ (average 4-5 m), the diameter - from 35 to $90 \mathrm{~m}$ (average $40-60 \mathrm{~m})$;

- the state of preservation of the kurgans; barrows destroyed by man, e.g. due to the extraction of earth, strong disturbance of the upper part of a kurgan (the presence of trenches or water tanks on top) and those which were used intensively as cemeteries were rejected;

- the state of preservation of the plant cover; it was assumed that the presence of typical steppe species, such as tuft grasses: Festuca valesiaca, Koeleria cristata and Stipa capillata was indicative of the relatively good condition of the plant cover.

The following microhabitats within the 26 kurgans were identified: T - top of the barrow; Ss - southern slope; Sn northern slope; Bs - southern foot; Bn - northern foot. In 
each microhabitat a floristic list was made and the abundance of each species was estimated according to a 3-point scale (1 - sporadic, 2 - infrequent, 3 - commonly found in a given microhabitat). A complete floristic list has already been published in the work of Moysiyenko and SudnikWójcikowska (2006).

In the present study the following parameters were taken into account with the aim of comparing the total flora of particular microhabitats: species richness and frequency; spectra of selected species groups, i.e. life forms, geographical-historical and socio-ecological groups; the mean number of species, as well as the average percentage of anthropophytes and the species group comprising therophytes and short-living perennials ( 2 and 3 -year-old) were determined for each microhabitat (Student's t-test was used to assess whether the means of two groups were significantly different).

Geographical-historical groups of species were defined according to the classification proposed by Kornaś (1981). The sociological amplitudes of each of the species (socioecological groups sensu Didukh 2000-2002) were presented by the authors in an earlier work. When determining the spectrum of socio-ecological groups of species in the present study, only the syntaxon which the species is most closely associated with, was taken into account. Further analysis showed that syntaxa represented by a relatively small number of species, comprising less than $5 \%$ of the total number of species in a microhabitat, were rejected.

The species nomenclature follows Mosyakin and Fedoronchuk (1999). The Latin names of syntaxa are given according to Solomakha (1996); Mirkin and Naumova (1998) and Matuszkiewicz (2001).

\section{RESULTS}

\section{General characteristics of the kurgan flora}

A total of 305 species of vascular plants were recorded on 26 kurgans in the desert steppe zone. The number of species on particular barrows ranged from 51 to $103 ; 82$ on average. Among the 305 species, the majority - over $77 \%$ - are native plants, of which at least 10 shall be considered as particularly interesting: Allium regelianum, Dianthus lanceolatus and Linaria biebersteinii listed in "Plants of Ukraine in the 1997 IUCN - Red List of Threatened Plants" (Mosyakin 1999), Senecio borysthenicus from the "Europeaen Red List" (Shelyag-Sosonko et al. 1996), Anacamptis picta (= Orchis picta), Stipa capillata and Tulipa schrenkii - the "Red Data Book of Ukraine" (Shelyag-Sosonko et al. 1996), Cerastium ucrainicum, Muscari neglectum and Quercus robur - the "Red Data List of Kherson Region" (Boiko and Podgajnyj 2002). All the above species are protected and their presence indicates the role of kurgans as refugia of steppe flora. The spectrum of life forms of the kurgan flora corresponds basically to that of the flora of the desert steppe zone (almost a half of the flora consisted of therophytes and short-living perennials). Species of alien origin constitute $23 \%$ of the kurgan flora, which does not indicate significant anthropogenic influence. Species with wide Mediterranean-Eurasian ranges predominated among anthropohytes. Only 9 species were synanthropic newcomers, i.e. kenophytes. The phytosociological range of the kurgan flora was quite wide. Species of two classes Festuco-Brometea and Stellarietea mediae were predominant, which also confirmed the semi-natural character of the kurgan flora.

\section{Comparison of the flora of various microhabitats \\ 2.1. Species richness and frequency}

The total number of species (Fig. 2) varied between microhabitats within the kurgans. The highest number of taxa was recorded at the north foot $(\mathrm{Bn})-83 \%$ of the total kurgan flora. Their number was almost twice as high as the number of species encountered on top of the barrows (T), which was floristically the poorest (48\% of the kurgan flora). The slopes of the kurgans $(\mathrm{Ss}, \mathrm{Sn})$ supported a lower number of species than the foot of the barrows (Bs, Bn). At the same time, both the north slope $(\mathrm{Sn})$ and foot $(\mathrm{Bn})$ were richer in species than the south facing slope (Ss) and foot (Bs) of the barrows. In the desert steppe zone harsh conditions exist on the top and the south facing slopes of the barrows. The higher number of species at the foot of the kurgans may be due to milder temperatures and higher soil moisture content. As a result mesophytes and a few tree species were noted. In addition, the influence of the surrounding area on the kurgan flora (thus the presence of field weeds, species from subhalophyte meadows and extensively used pastures, halophytes from the nearby solonetz and solonchak (c.f., section 2.4) is much stronger at the foot of the barrows.

Some differences were also detected when comparing the total number of species in the particular habitats with the mean number of species per microhabitat (Fig. 2). The average number of species on top of a barrow was the lowest and amounted to 28 . The differences in mean species number between the top and every other microhabitat are statistically significant at the $99.9 \%$ level. The mean values were quite similar for the north/south slope (Ss or Sn) and north/south foot (Bs or Bn). Significant differences at the $95 \%$ level were found only for the Bs/Bn pair. The small differences in the mean values indicate that the greater total richness of species at the foot of the kurgans is determined by species which constitute an unstable and changeable element of the flora (e.g. weeds, halophytes).

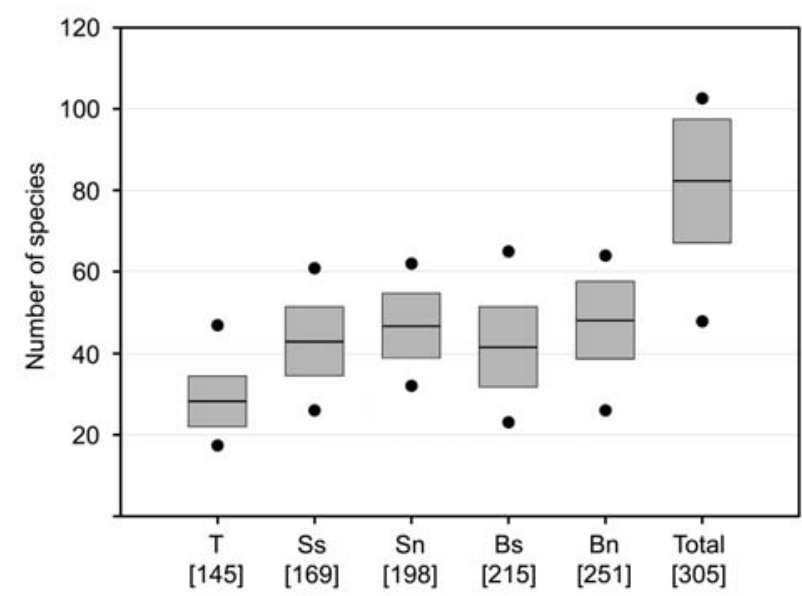

Fig. 2. Mean, minimum and maximum number of species in particular microhabitats and on a kurgan (enclosed in square brackets are the total number of species in a particular microhabitat and on all the kurgans studied). Abbreviations: T - top of the barrow; Ss - southern slope; $\mathrm{Sn}$ northern slope; Bs - southern foot; $\mathrm{Bn}$ - northern foot. 


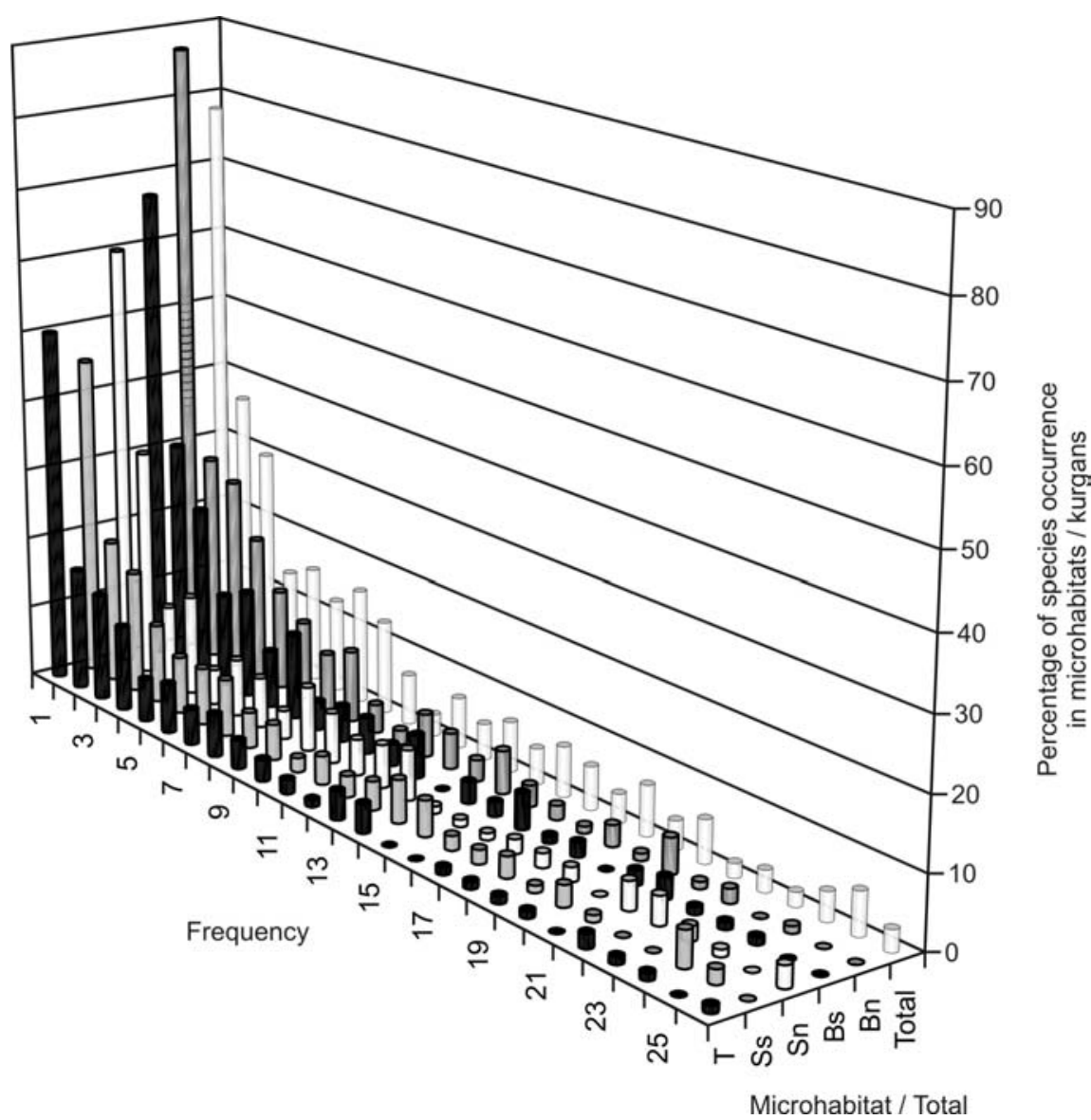

Fig. 3. The frequency of species in particular microhabitats and on a kurgan. T, Ss, Sn, Bs, Bn - see Fig. 2.
The analysis of the frequency diagram (Fig. 3) showed that species of rare and sporadic occurrence (encountered on less than $25 \%$ of all the kurgans surveyed), prevailed in the flora of barrows. The group of "common" species, which were present on at least $75 \%$ of the kurgans, was much smaller. Most of them were recorded on the slopes (Ss, Sn), which confirms that the flora of slopes is more stable, whereas the foot $(\mathrm{Bs}, \mathrm{Bn})$ supports a higher number of rare, sporadic and casual species encountered only on 1-3 kurgans.

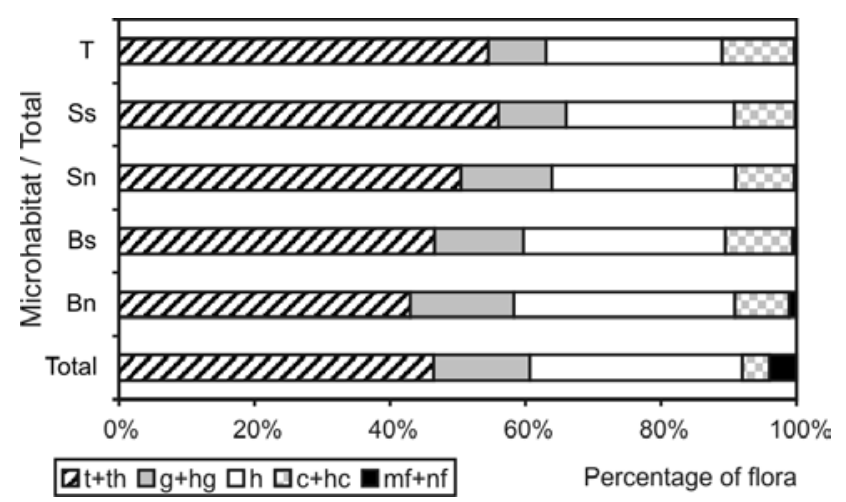

\subsection{Spectrum of life forms}

Analogous trends were found when comparing the spectra of life forms for the flora of the particular habitats and the total flora of kurgans (Fig. 4A):

- a high proportion of short-living perennials (2 and 3-year-old) and therophytes;

- the second largest group were hemicryptophytes (which usually dominate in the flora of the temperate zone);

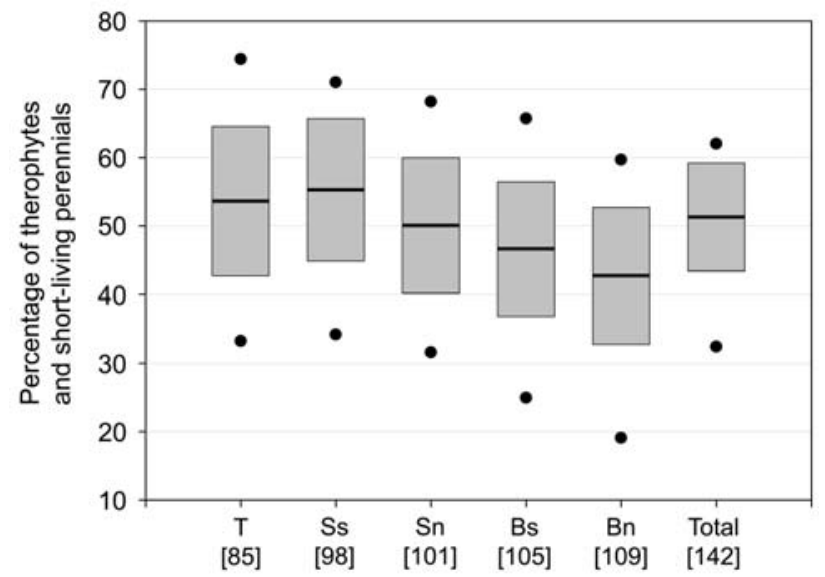

Fig. 4. Life forms:

A) spectrum in the flora of particular microhabitats and all the kurgans studied; B) mean percentage, minimum and maximum number of therophytes and short-living perennials in particular microhabitats and on a kurgan (enclosed in square brackets are the total number of therophytes in a particular microhabitat and on all the kurgans studied)

Abbreviations: $\mathrm{t}$ - therophytes; th - short-living perennials (2 and 3-year-old); $\mathrm{g}$ - geophytes; hg - geophytes-hemicryptophytes (perennials, some of whose perennating buds (shoot system) remain on the soil surface and underground; $\mathrm{h}$ - hemicryptophytes; $\mathrm{hc}$ - hemicryptophytes-chamaephytes - perennials whose perennating buds remain on or above (within $0.25 \mathrm{~m}$ ) the soil surface; $\mathrm{c}$ - chamaephytes; $\mathrm{mf}$ - megaphanerophytes; $\mathrm{nf}-$ nanophanerophytes. T, Ss, Sn, Bs, Bn - see Fig. 2. 
- a low percentage of phanerophytes and chamaephytes, which is also characteristic of the desert steppe subzone.

However, a more detailed comparative analysis indicated significant differences between the flora of the particular microhabitats:

- the higher proportion of phanerophytes in the total flora of kurgans, and their small contribution to the flora of particular microhabitats indicate that there is a diversity of tree and shrub species on the barrows, but the particular species occur at low frequency, which confirms the specific character of the zone. Phanerophytes were practically absent on the slopes and top of the barrows. Only few of them were found at the foot, but their representation was higher on the north side of the barrows;

- a slightly higher proportion of chamaephytes at the foot of the kurgans.

- a relatively small proportion of geophytes was recorded in all the microhabitats. However, they were more often found at the foot and on the north slope of the kurgans;

- therophytes and short-living perennials were mostly represented in the flora of the top and slopes of the kurgans, where the conditions are more extreme; their proportion was lower in the case of the north foot;

- a total of 142 species of therophytes and short-living perennials were recorded on all the kurgans investigated. The mean number of this species per kurgan was estimated at 52 (Fig. 4B). The differences in the mean number of the above group of species in the flora of microhabitats are significant when microhabitats $\mathrm{Bn}$ and $\mathrm{Bs}$ are compared with the other microhabitats within the kurgan (T, Sn, Ss); an insignificant difference was found for the Bs/Sn pair only.

\subsection{Spectrum of groups}

in the geographical-historical classification of plants

The highest percentage of synanthropic species, both native and alien, in the flora of the microhabitats was recorded on top (sometimes altered due to human activities) and at the foot of the kurgans, particularly on the south side (Fig. 5). A comparative analysis of the total flora of the particular microhabitats and the total flora of kurgans showed that non-synanthropic species (especially halophytes and steppe species) and kenophytes were the most variable groups among the flora of the microhabitats. Hemiapophy-

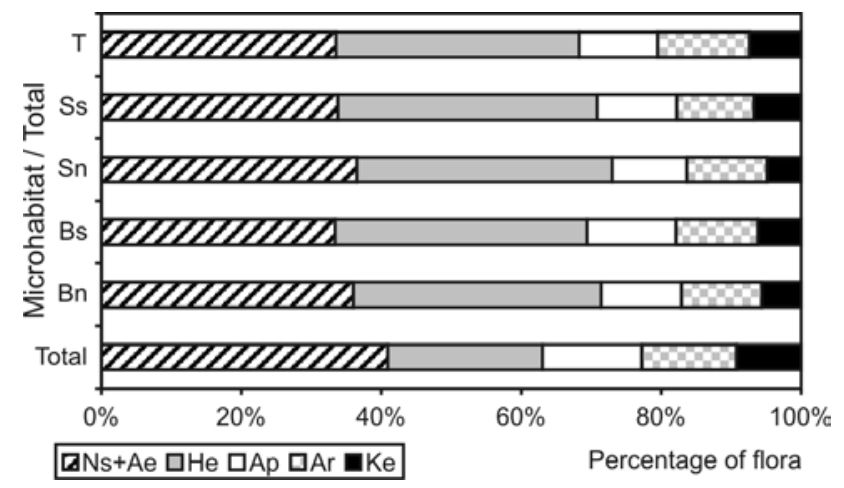

Fig. 5. Groups of the historical-geographical classification of plants spectrum in the flora of the particular microhabitats and all the kurgans sampled. Abbreviations: historical-geographical classification of species: Ns - native species; Ap - apophytes; He - hemiapophytes; Ae - oekiophytes; Ar - archaeophytes; Ke - kenophytes. T, Ss, Sn, Bs, Bn - see Fig. 2. tes were found to be a relatively stable element of the flora (similar species composition in the various microhabitats).

The total number of anthropophytes (archaeophytes and kenophytes) on the kurgans amounted to 69. Their mean number per kurgan was 17 . Test $\mathrm{T}$ did not indicate any significant differences in the mean share of anthropophytes in the flora between the particular microhabitats.

\subsection{Socio-ecological groups of species}

A total of 27 syntaxa in the rank of classes were represented in all the microhabitats surveyed (Moysiyenko and Sudnik-Wójcikowska 2006). The most frequent syntaxa, whose species comprised more than $10 \%$ of the total flora of a microhabitat, were: Festuco-Brometea, Stellarietea mediae. However, classes which included grassland communities such as: Polygono-Artemisietea austriacae, FestucoPuccinellietea, Festuco vaginetea and Molinio-Arrhenatheretea were represented by species comprising $5-10 \%$ of the total number of species in all or almost all microhabitats.

The number of species from this syntaxa within every microhabitat is presented in the diagram (Fig. 6). The diversity of the flora is much higher at the foot of the kurgan. The number of steppe species is lower here but a higher of synanthropes (from the class Stellarietea mediae) and halophytes (from the class Festuco-Puccinellietea) is noted.

Considerable differences in the proportion of species from the particular syntaxa were detected between the various microhabitats (Fig. 7, however, it includes a larger number of syntaxa, which were represented by more than $1 \%$ of the species in the flora of particular microhabitats). The class comprising xerothermic grasslands, i.e. FestucoBrometea, was best represented on the slopes (mostly on the north slope) and top of the kurgans. This tendency is not marked so well for species representing dry grazed grasslands (Polygono-Artemisietea austriacae). The percentage of species associated with halophilous communities (Asteretea tripolium and subhalophilous grasslands Festuco-Puccinellietea) was highest at the foot of the barrows, which was attributed mainly to higher soil moisture levels at the foot, as well as the presence of salinized soils in its immediate vicinity. As expected, meadow mesophyte species from the class Molinio-Arrhenatheretea (mainly from the orders Althaetalia officinalis and Galietalia veri) were usually encountered at the foot of the kurgans.

Among the classes which include synanthropic communities, the class Stellarietea mediae mainly comprising communities of therophytes was most frequently represented on the top and the south slope of the barrows. The remaining syntaxa which included synanthropic communities composed essentially of perennial species (Artemisietea and especially Agropyretea intermedio-repentis) were best represented at the foot of the kurgans.

A group of species referred to as "others" was also most frequently noted at the foot of the kurgans, which confirms the heterogenous character of the surrounding area (cf. Table 1). The following syntaxa were represented mainly by the above group of species: Crypsietea aculeatae, CrithmoStaticetea, Thero-Salicornietea, Salicornietea fruticosae, Asteretea tripolium, Galio-Urticetea. In addition the foot supported a small number of tree species (associated with the class Robinietea), which had been introduced from plantations of trees or windbreaks. 

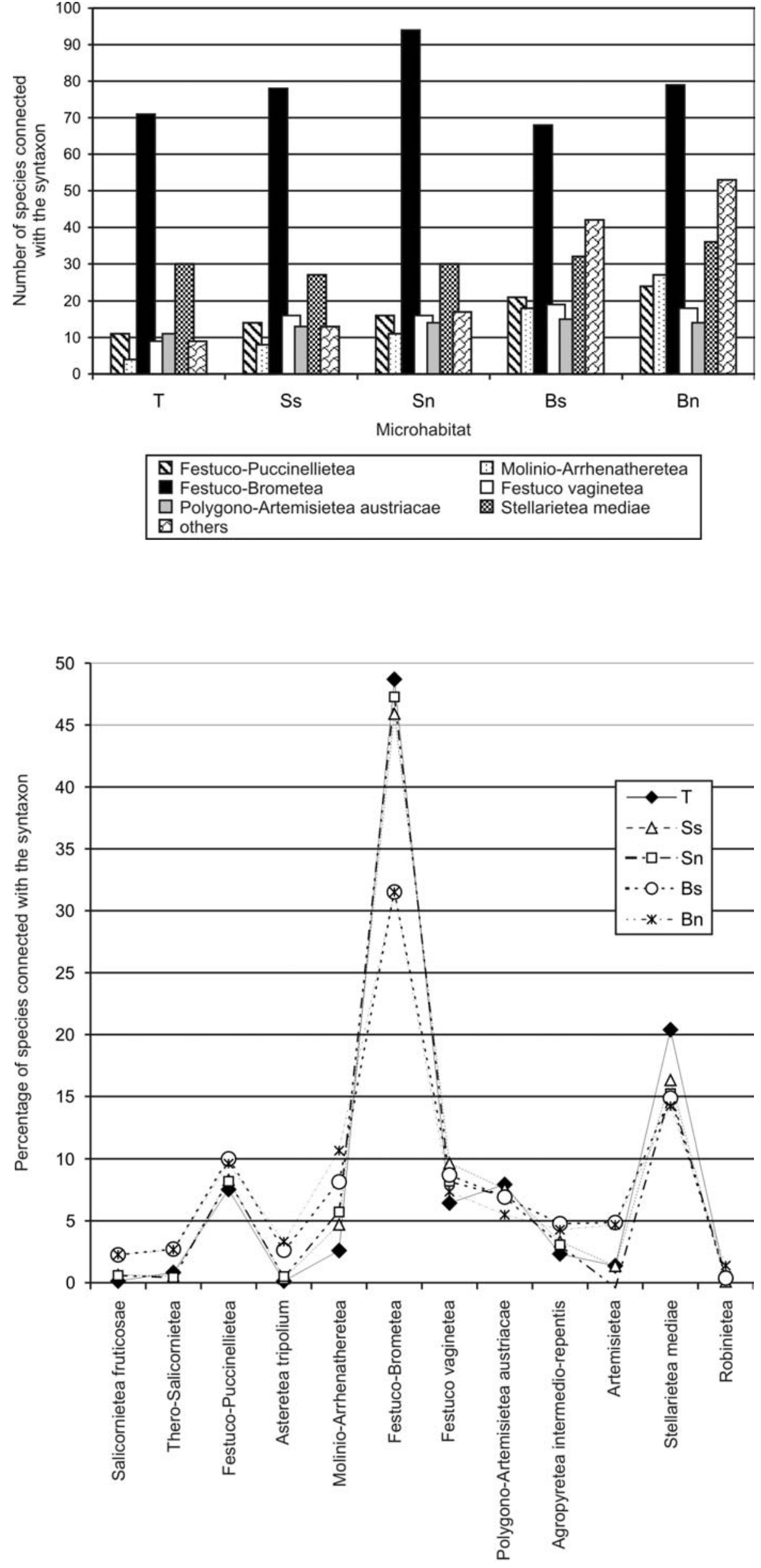

Syntaxon
Fig. 6. The number of species from different syntaxa in the flora of particular microhabitats. Only 6 syntaxa were taken into consideration, which were represented by species comprising more than $5 \%$ of the the total number of species in at least one microhabitat. Abbreviations: T, Ss, Sn, Bs, Bn - see Fig. 2.

Fig. 7. The percentage of species from different syntaxa of the class rank in the flora of particular microhabitats. The syntaxa which were represented by species comprising at least $1 \%$ of the total number of species in a microhabitat were taken into consideration. Syntaxa ordered along the gradient:

- from more to less halophilous;

- from natural to synanthropic;

(the lines connecting the points make it easier to characterize the microhabitats)

Abbreviations: T, Ss, Sn, Bs, Bn - see Fig. 2. 


\section{DISCUSSION}

The relationship between the floristic composition and slope exposition as well as altitude (site elevation) is generally recognized. Therefore it would be interesting to note if such a relationship exists in the case of kurgans, which are relatively small structures in the desert steppe zone. The comparative analysis of the flora showed distinct differences between the particular microhabitats. The following tendencies were observed:

- impoverishment of the flora on top of the kurgans; the steppe species comprised an estimated $50 \%$ of the flora, when the total number of species was lower; halophilous and meadow species were less numerous; synanthropic species, mainly from the class Stellarietea mediae comprised about $20 \%$ of the flora of top of the barrows;

- the total flora of slopes was poorer in species but more "stable" than the flora of the foot; species associated with the class Festuco-Brometea accounted for more than $45 \%$ of the flora of slopes (exceeding 30\% - at the foot);

- the total flora of the foot was richer in species and more diversified than that of the other microhabitats (the important role of halophytes, meadow species, weeds and some trees). However, the mean number of species at the foot was quite similar to that of the slopes;

- the total flora of the north side - both slope and foot contained more species than the flora of the south side of the kurgans.

The above differences between the flora of particular microhabitats were detected even though most of the investigated kurgans ranged from 4-5 $\mathrm{m}$ in height. Perhaps the spectra of Ellenberg's indicator values (Lindacher 1995) could also be used to differentiate the various microhabitats. However, the lack of data for a large number of Ukrainian species makes this type of analysis impossible in the present study (Didukh 2000-2002).

It should be noted that floristic differences between the various microhabitats are marked in spite of the "uniform impact" of animals which find shelter on the kurgans. Synanthropic species find more suitable conditions for growth in disturbed places, near burrows, hollows and dens located on slopes and at the foot of the kurgans. Their presence does not seem to be determined by slope exposition or site elevation. Perhaps the differences between the spectra of synanthropic species in particular microhabitats would be more significant if there were no zoogenic influences (this mainly applies to anthropophytes - the mean proportion of the above group of species was not significantly different between the microhabitats studied). Therophytes also inhabit disturbed places near burrows and dens. Significant differences between the microhabitats were, however, found with regard to the above group of species. The differences probably would have been even bigger if no animal activity had occurred within the specified area.

Although the kurgans in southern Ukraine have been thoroughly investigated by archaeologists, the floristic data for kurgans are very scarce (Kondratyuk and Chuprina 1992). Currently, the flora of kurgans from other steppe subzones (west Pontic grass steppe = "tipczakovo-kovylnaja step biednoje raznotravie" and west and central Pontic herb-rich grass and herb-grass steppe = "tipczakovo-kovylnaja step bogatoje raznotravje") and the forest-steppe zone is being investigated by the authors. Further floristic analysis will show the extent of the differentiation of the microhabitats within the kurgans in the above 3 zones.

Similar structures were researched in Poland, which lies within the zone of deciduous forests and about $1000 \mathrm{~km}$ northwest of the area surveyed in Ukraine. The work of Faliński (1972; see also: Faliński et al. 2005) is worthy of recognition. The above author investigated the kames of the Bielsk Plain, which are of different origin and age to kurgans, but are similar in shape (their height ranges from 4 to $8 \mathrm{~m}$ ); their soil is similar to pararendzina, $\mathrm{pH}$ above 7 . The grasslands developing on kames are similar to steppe grasslands ("north steppes") and are well differentiated, which is attributed to a variety of temperature, light and moisture conditions. Faliński identified a typical variant of the association Phleo-Veronicetum spicatae on the south slopes, and a variant with Sedum acre in the warmest places, as well as grasslands similar to Arrhenatherum elatius meadow on the north slopes.

As already mentioned, kurgans in Poland have also been surveyed (Cwener and Towpasz 2003; Cwener 2004, 2005). The barrows from the Malopolska Region date back to Trzciniec culture and string pottery culture, and their height ranges from 1.5-6 $\mathrm{m}$. The above authors did not analyse the flora of the particular microhabitats. However, they noted differences in the distribution of some species within the kurgans which was related to slope exposition (insolation).

Celka (1999) investigated earthworks (10-200 $\mathrm{m}$ in diameter), which are somewhat different and are more differentiated structures than kurgans. The author defined the degree of hemeroby (i.e. mainly the anthropogenic factor) as a criterion for differentiating the habitats within the earthworks. However, the differentiation of microhabitats which are subject to strong human pressure (e.g. road and railway embankments, city walls) is a separate problem and has been analysed much more frequently.

\section{ACKNOWLEDGEMENTS}

The study was supported by the Committee for Scientific Research in Poland - Grant 2 P04G 04627.

\section{LITERATURE CITED}

ARTEMENKO I.I., BARAN V.D., BIBIKOV S.M., DOBZHENOK V.J., LESKOV O.M., TELEGIN D.JA., TERENOZHKIN O.I. (eds). 1975-1985. Archeologija Ukrainskoj SSSR. Vol. 2, 3. Naukova Dumka Press, Kiev, pp. 500+502. (in Ukrainian)

BARCZI A., JOÓ K. 2000. Kurgans: Historical and ecological heritage of the Hungarian Plane. Elöadás. International Conference on Multifunctional Landscapes. Roskilde, Dánia, 2000. október 18-21. Conference Material, p. 199-200.

BARCZI A., JOÓ K. 2002. Botanical and soil survey of kurgans (Great Hungarian Plain, Hungary). 17th World Congress of Soil Science, CD ROM. 14-21. August 2002, Bangkok, Thailand.

BARCZI A. 2003. Data for the botanical and pedological surveys of the Hungarian kurgans (Great Hungarian Plain, Hortobagy. Thaiszia-J. Bot. 13: 113-126.

BILYK G.I., OSYCHNYUK V.V., TKACHENKO V.S., GRYN F.O., KOSETS M.I. 1973. Roslynnist URSR. Stepy, kam'yanysti vidslonennya, pisky. Naukova Dumka, Kyiv, pp. 428. (in Ukrainian)

BOHN U., GOLLUB G., HETTWER C., NEUHÄUSLOVÁ Z., RAUS T., SCHLÜTER H., WEBER H. (eds). 2000. Karte der 
natürlichen Vegetation Europas, Maßstab 1:2 500 000. [Map of the Natural vegetation of Europe. Scale 1:2 500 000]. Bundesamt für Naturschutz, Bonn.

BOIKO M.F., KOTOVS'KYJ I.M., ALIFANOFF O.P., BOIKO V.M., CHORNYJ S.G., RUSINA L.YU., FENTISOVA T.O. 1998. Pryroda Khersons'koyi oblasti. Phytosociocentre, Kyiv, pp. 3-119. (in Ukrainian)

BOIKO M.F., PODGAJNYJ M.M. 2002. Chervonyj spysok Khersonskoyi oblasti. Ajlant, Kherson, pp. 3-26. (in Ukrainian)

CELKA Z. 1999. Rośliny naczyniowe grodzisk Wielkopolski. Prace Zakładu Taksonomii Roślin UAM w Poznaniu 9. Bogucki Wydawnictwo Naukowe, Poznań, pp. 5-159. (in Polish with English summary)

CWENER A. 2004. Rośliny naczyniowe kurhanów w dorzeczu dolnej Szreniawy i Nidzicy (Wyżyna Małopolska, południowa Polska). Fragm. Flor. Geobot. Polonica 11: 27-40. (in Polish with English summary)

CWENER A. 2005. Różnorodność flory roślin naczyniowych kurhanów w dorzeczu Szreniawy i Nidzicy (Wyżyna Małopolska, południowa Polska). In: K. Wasylikowa, M. Lityńska-Zając, A. Bieniek. Roślinne ślady człowieka. Botanical Guidebooks 28: 297-304. (in Polish with English summary)

CWENER A., TOWPASZ K. 2003. Kurhany jako ostoje różnorodności gatunkowej w rolniczym krajobrazie Płaskowyżu Proszowickiego. Chrońmy Przyr. Ojczystą 59 (6): 57-65. (in Polish with English summary)

DIDUKH YA. (ed.). 2000-2002. Ekoflora Ukrainy. Vol. 1-3. Phytosociocentre, Kyiv. (in Ukrainian)

FALIŃSKI J.B. 1972. Antropogeniczne zagrożenie i program ochrony muraw kserotermicznych na kemach północnej części Równiny Bielskiej. Phytocoenosis 1: 287-306. (in Polish with English summary)

FALIŃSKI J.B., BER A., KOBYLIŃSKI Z., KWIATKOWSKAFALIŃSKA A. (eds) 2005. Haćki. Zespół przyrodniczo-architektoniczny na Równinie Bielskiej. Białowieska Stacja Geobotaniczna Uniw. Warsz., Państwowy Instytut Geologiczny, Instytut Archeologii i Etnologii PAN, Zakład Ekologii i Ochrony Przyrody Uniw. Warsz., Białowieża-Warszawa, pp. 144. (in Polish)

KONDRATYUK E.N., CHUPRINA T.T. 1992. Kovylnye stepi Donbassa. Naukova Dumka, Kiev, pp. 172. (in Russian)

KORNAŚ J. 1981. Oddziaływanie człowieka na florę: mechanizmy i konsekwencje. Wiad. Bot. 25: 165-182. (in Polish)

KUBCZAK J. 1978. Kurhany arystokracji scytyjskiej. Wyd. Uniwersytetu A. Mickiewicza w Poznaniu, Ser. Historia Sztuki 9: 7-167. (in Polish with English summary)
LAVRENKO E.M., KARAMYSHEVA Z.V., NIKULINA R.I. 1991. Stepi Eurazii. Izdat. Nauka, Leningrad, pp. 5-143. (in Russian)

LINDACHER R. (ed.) 1995. Phanart. Datenbank der Gefässpflanzen Mitteleuropas. Enklärung der Kennzahlen, Aufbau und Inhalt. Veröff. Geobot. Inst. Rübel, Zürich 125: 1-436.

MATUSZKIEWICZ W. 2001. Przewodnik do oznaczania zbiorowisk roślinnych Polski. In: Faliński J.B. (ed.) Vademecum Geobotanicum. Wydawnictwo Naukowe PWN, Warszawa, pp. 5-537. (in Polish)

MIRKIN B.M., NAUMOVA L.G. 1998. Nauka o rostitelnosti. Gilem, Ufa, pp. 408. (Russian with English summary)

MOSYAKIN S.L. 1999. Plants of Ukraine in the 1997 IUCN Red List of Threatened Plants. Ukr. Bot. Zhurn. 56 (1): 79-88.

Mosyakin S.L., Fedoronchuk M.M. 1999. Vascular plants of Ukraine. A nomenclatural checklist. National Academy of Sciences of Ukraine, M. G. Kholodny Institute of Botany, Kiev, pp. 5-346.

MOYSIYENKO I.I., SUDNIK-WÓJCIKOWSKA B. 2006. The flora of kurgans in the desert steppe zone of southern Ukraine. Chornomor. Bot. J. 2.1: 5-35.

OLENKOVS'KYJ M. 1997. Rozkryti i ne rozkryti taemnytsi istorii ta pryrody Pivdennoyi Ukrayiny. Izdat. Lileya, Kherson, pp. 62. (in Ukrainian)

PACZOSKI J. 1917. Opisanie rastitelnosti Khersonskoj gubernii. Vypusk 2. Stepi. Parovaya Tipo-litografiya preem. O. D. Khodushinoj, Kherson, pp. 317. (in Russian)

PACZOSKI J. 1933. Szata roślinna kurhanu króla Władysława Warneńczyka. PTPN. Prace Komisji Mat.-Przyr., Ser. B 6: 157-172. (in Polish)

SHELYAG-SOSONKO YU.R., ZAVERUKHA B.V., PARTYKA L.YA., YUNGER V.P., BLUM O.B., VASSER S.P., DUDKA I.O. 1996. Chervona knyga Ukrayiny. Roslinnyj svit. Ukrayinska Entsyklopediya, Kyiv, pp. 5-608. (in Ukrainian with English summary)

SHILOV JU.A. 1991. Itogi 20-letnich issledovanij kurganov Khersonshchiny. In: A.V. Gavrilov (ed.), Problemy archeologii severnogo Prichernomor'ya (k 100-letiju osnovanija Khersonskogo muzeya drevnostej). Khersonskoje Oblasnoje Upravlenie Kultury, Kherson, pp. 21-26. (in Russian)

SKLYAR O.S., KHILCHENKO P.O. 1969. Grunty Khersonskoy oblasti. Mayak, Odessa, pp. 60. (in Ukrainian)

SMIRNOV A. 1974. Scytowie. PIW, Warszawa, pp. 217. (in Polish)

SOLOMAKHA V.A. 1996. Sintaksonomia rostitelnosti Ukrainy. Phytosociocentre, Kiev, pp. 6-101. (in Ukrainian) 